Internet based International Master Program / Kurbel Karl // Proceedings on the 7th International Conference on Technology Supported Learning and Training; Berlin, Germany / ICEF Berlin GmbH (Eds.) Online Educa. - 2001. - November. - P. 133-136. 11. Mobile Learning: a Handbook for Educatorsand Trainers / Editedby: Agnes KukulskaHulme, John Traxler. - Routletge, 2005. - 192 p. 12. Sharples M. A Theory of Learning for the Mobile Age / Sharples M., Taylor J., Vavoula G. // The Sage Handbook of E-Learning Research / R. Andrews \& C. Haythornthwaite (eds.). - London: Sage, 2007. - P. 21-47. 13. Traxler J. Defining, Discussing, and Evaluating Mobile Learning : The moving finger writes and having writ... / Traxler J. // International Review of Research in Open and Distance Learning. - 2007. - June. Volume 8. - Number 2. 14. Yousuf M. I. Effectiveness of mobile learning in distance education / Muhammad Imran Yousuf // Turkish Online Journal of Distance Education-TOJDE. -2007. - October. Volume 8. Number 4. - P. 114-124.

УДК 004:378

\author{
Н. Т. Тверезовська, \\ доктор пед. наук, професор, \\ Наиіональний університет біоресурсів $i$ \\ природокористування України
}

\title{
ЗАКОНОМІРНОСТІ ФУНКЦІОНУВАННЯ ІНФОРМАЦІЙНИХ ТЕХНОЛОГІЙ
}

У статті розглянуто інновації як передумову виникнення інформаційних технологій; розкрито їх функціонування; показано циклічний процес зародження $і$ згасання інформаиійних технологій.

Ключові слова: інновачії, інформачійні технології, ииклічність, фундаментальність.

В статье рассмотрены инновачии как предпосылки возникновения информационных технологий; раскрыто их функиионирование, показан циклический процесс зарождения и угасания информачионных технологий.

Ключевые слова: инновачии, информачионные технологии, иикличность, фундаментальность.

The article describes the innovation as a prerequisite for the birth of information technology is considered, their operation is disclosed, a cyclic process of birth and decay of information technology is shown.

Key words: innovation, information technology, cyclical, fundamental.

Умови існування людства, що вступило у XXI століття, висувають нові вимоги до вищої освіти. Глибоке усвідомлення інноваційних явищ, уміння їх розв'язувати за допомогою 
неординарних методів неможливе без оволодіння інформаційними технологіями.

Створення в Україні нової системи освіти, зорієнтованої на входження в єдиний європейський освітній простір, супроводжується істотними змінами в педагогічній теорії і практиці, що зумовило появу освітніх інновацій, покликаних суттєво змінити навчально-виховний процес. Інновації в освіті - ключова умова успішного розвитку інформаційного суспільства, які потребують пріоритетного забезпечення відповідними ресурсами.

Кардинальним завданням професійної підготовки у зазначених умовах $\epsilon$ фундаменталізація, яка передбачає зміну співвідношення між прагматичним i загальнокультурним компонентом, зміну змісту і методології навчального процесу, зорієнтованого на вивчення фундаментальних законів природи і суспільства, формування цілісних уявлень про наукову картину світу тощо. Оновлення, що відбувається в освіті, наближається до рівня соціальних, політичних, психологічних, педагогічних, методологічних вимог суспільства.

У педагогічній практиці інновації знайшли свій вияв у трьох основних формах:

- інновації як теоретичні концепції нововведень, що $\epsilon$ втіленням прогресивної думки про нову педагогіку;

- інновації як розроблені конкретні технології перспективних завдань освіти, виражених у дидактичних і виховних новаторських системах, методиках і практичних засобах;

- педагогічні реформи як масове впровадження інновацій у практику вищої школи.

Усе це говорить про те, що проникнення інноваційних технологій у сферу освіти дозволяє педагогам модернізувати мету, зміст, методи, засоби і організаційні форми навчання. Також зауважимо, що інформатизація освіти є не тільки наслідком, але й стимулом розвитку інноваційних технологій, яка зумовлює прискорений соціально-економічний розвиток суспільства.

Інновація педагогічного процесу - навчальний процес, який має свої характерні особливості, є складним і багатоплановим феноменом, охоплюючи за своїм змістом взаємодію індивідів, і спрямований на розвиток, перетворення об'єкта, переведення його у якісно новий стан, системну діяльність щодо створення, засвоєння та застосування нових засобів; особливий вид творчої діяльності, що об’єднує різноманітні 
операції і дії, спрямовані на одержання нових знань, технологій, систем (М. Артеменко, I. Богданова, I. Дичківська, Т. Калюжна та ін.).

Мета статmi - розкрити закономірності функціонування інформаційних технологій у навчальному процесі.

Складний і тривалий інноваційний процес проходить дві стадії:

- формувальну - створення філософії інновації;

- уточнювальну - інновація конкретизується в основних категоріях (елементах) навчального процесу: концептуальній, цільовій, змістовній, процесуальній, технологічній та оціночній.

Серед чинників, що негативно впливають на інноваційний розвиток, не останню роль відіграє відрив від практики, суттєві зміни в суспільстві й на виробництві, іiі матеріальне забезпечення, що суттєво позначилося як на статусі викладача, так і на мотивації підготовки фахівців.

Розв'язання соціальних та економічних проблем, що стоять перед вищою освітою, буде залежати від того, чи вдасться забезпечити максимальну мобілізацію можливостей і реалізацію здібностей кожної людини як суб'єкта діяльності.

Такий підхід із позиції особистісно зорієнтованого навчання, дає можливість кожному студентові оптимально пристосуватися до професійної діяльності за рахунок максимального використання індивідуальних здібностей. Водночас інформатизація навчального процесу є одним із видів інноваційної діяльності.

За визначенням І. Дичківської, інновачійне навчання це «зорієнтована на динамічні зміни в навколишньому світі навчальна та освітня діяльність, яка грунтується на розвитку різноманітних форм мислення, творчих здібностей, високих соціально-адаптаційних можливостей особистості» [3, с. 9].

Отже, інновація - це: 1) результат творчого пошуку оригінальних, нестандартних рішень різноманітних педагогічних проблем; 2) процес оновлення чи вдосконалення теорії i практики освіти, який оптимізує досягнення ії мети.

Проте в навчальних закладах зберігаються суперечності між: «фронтальними» формами навчання та індивідуальними способами навчально-пізнавальної діяльності кожного студента; необхідністю індивідуалізації й диференціації навчання та недосконалим змістом спеціальних (профільних) дисциплін. Одним із важливих напрямків усунення названих супе- 
речностей є розроблення і введення інноваційних технологій, які будуються на засадах особистісно зорієнтованої освітньої парадигми. А це в першу чергу - інформаційнокомунікаційні технології.

Як показує аналіз педагогічної практики, інновація є предметом особливої діяльності людини, яка не задоволена традиційними умовами, методами, способами і прагне не лише новизни змісту реалізації своїх зусиль, а передовсім якісно нових результатів.

Важливою умовою інноваційного процесу в педагогічній діяльності є творчість: досягнення творчого рівня розвитку особистості можна вважати найвищим результатом будь-якої педагогічної технології.

Теоретичним джерелом розвитку творчої особистості в галузі техніки є закони розвитку технічних систем, які передбачають аналіз різноманітної патентної та науково-технічної інформації. Як правило, вдосконалення технічних систем відбувається у процесі реалізації винахідницьких завдань 3 дотриманням відповідної системи стандартів. Значну роль відіграє систематизований інформаційний фонд, який постійно оновлюється, збагачується.

За визначенням М. Фіцули, інформаційні технології навчання - це «методологія і технологія навчально-виховного процесу з використанням новітніх електронних засобів» [5, c. 192]. Ми не згодні з таким твердженням, оскільки новітні електронні засоби себе вже вичерпали. На зміну їм прийшли мережеві технології, які в режимі on-line допомагають студентові навчатися.

Отже, проникнення сучасних інформаційних технологій у сферу освіти дозволяє педагогам модернізувати мету, зміст, методи, засоби й організаційні форми навчання, що $є$ основою інформатизації освіти. А технологічне переоснащення навчального процесу, поява нового змісту, методів, засобів і організаційних форм навчання $є$ необхідністю, яка забезпечує досягнення вище окреслених цілей.

Педагогічна технологія функціонує як наука, що досліджує найраціональніші шляхи навчання, і як система способів, принципів і регулятивів, які застосовуються у навчанні, i як реальний процес навчання. Проте з яких би боків її не розглядати, головним у педагогічній технології $\epsilon$ розроблення, деталізація інструментальних аспектів педагогічних процесів. Створення ж нової технології, як правило, є наслідком неза- 
доволення результатами навчання й виховання, а також неефективністю педагогічної діяльності як професійного експромту.

Зокрема, інформаційні технології навчання (ITH) набувають особливого значення в опануванні методологією дослідження, проектування та інших видів інтелектуальної діяльності, оскільки випускників вищої школи слід готувати саме до неї. Еволюційні зміни повинні грунтуватись на науковій раціональності та збереженні всього позитивного, що було напрацьованими у попередні десятиліття. Усе це дає підстави визнати, що інформаційні технології навчання зароджуються, розвиваються і гармонічно взаємодіють поряд із традиційними, створюючи колообіг (див. рис. 1).

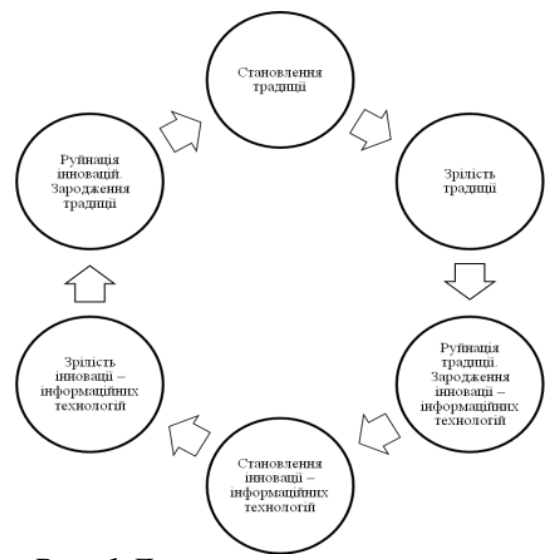

Рис. 1 Діалектика взаємоперетворення інновацій на традииійні технологіі

Завдяки своїм особливостям ITH принципово відрізняються від традиційних (див. табл. 1).

Отже, процес становлення педагогічної технології охоплює декілька етапів: виникнення суспільної потреби $\rightarrow$ фундаментальні дослідження $\rightarrow$ розробка нових технологій $\rightarrow$ відображення новостворених технологій у навчальнопрограмній та навчально-методичній документації.

Таблиия 1

Відмінності між традиційними й інформаційними технологіями навчання

\begin{tabular}{|l|l|l|}
\hline \multicolumn{1}{|c|}{$\begin{array}{c}\text { Характеристика } \\
\text { процесу навчання }\end{array}$} & \multicolumn{1}{|c|}{ Традиційний процес } & \multicolumn{1}{|c|}{ Інформаційний процес } \\
\hline Кінцева мета & $\begin{array}{l}\text { Задоволення традиційної, } \\
\text { суспільної потреби }\end{array}$ & $\begin{array}{l}\text { Задоволення нової суспіль- } \\
\text { ної потреби }\end{array}$ \\
\hline
\end{tabular}




\begin{tabular}{|l|l|l|}
\hline $\begin{array}{l}\text { Шляхи досягнення } \\
\text { мети }\end{array}$ & $\begin{array}{l}\text { Лекції, практичні занят- } \\
\text { тя, контрольні роботи, } \\
\text { самостійна робота }\end{array}$ & $\begin{array}{l}\text { Створення комплексного } \\
\text { інформаційного забезпе- } \\
\text { чення }\end{array}$ \\
\hline $\begin{array}{l}\text { Ризик при досягненні } \\
\text { мети }\end{array}$ & Низький & Високий \\
\hline Тип процесу & Неперервний & Перервний \\
\hline $\begin{array}{l}\text { Керованість проце- } \\
\text { сом, можливості } \\
\text { планування }\end{array}$ & $\begin{array}{l}\text { Висока керованість. } \\
\text { Оптимальні можливості } \\
\text { планування }\end{array}$ & $\begin{array}{l}\text { Низька керованість. } \\
\text { Стратегічне планування }\end{array}$ \\
\hline Плани & Короткострокові & $\begin{array}{l}\text { Довгострокові (поступове } \\
\text { опанування знаннями за } \\
\text { рівнями складності), 3 } \\
\text { коригуванням (за необхід- } \\
\text { ності) }\end{array}$ \\
\hline $\begin{array}{l}\text { Розвиток системи, у } \\
\text { межах якої здійсню- } \\
\text { ється процес }\end{array}$ & $\begin{array}{l}\text { Збереження рівня розви- } \\
\text { тку (середній) } \\
\text { розвитку. новий рівень } \\
\text { Розробка проекту і програ- } \\
\text { ми реалізації стратегічних } \\
\text { змін }\end{array}$ \\
\hline $\begin{array}{l}\text { Ступінь узгодженос- } \\
\text { ті інтересів учасників } \\
\text { процесу }\end{array}$ & Високий & $\begin{array}{l}\text { Високий (підвищення тво- } \\
\text { рчої активності) }\end{array}$ \\
\hline $\begin{array}{l}\text { Форми організації } \\
\text { Жорсткі, що грунтуються }\end{array}$ & $\begin{array}{l}\text { Гнучкі (як навчання, так і } \\
\text { самопідготовка може здій- } \\
\text { снюватися у зручний для } \\
\text { студента час і зручному } \\
\text { місці) }\end{array}$ \\
\hline
\end{tabular}

Будь-яка педагогічна, зокрема й інформаційна технологія навчання, є функціональною на певних рівнях.

1. Загальнопедагогічному - цілісний освітній процес у регіоні, освітньому закладі, на певному рівні навчання чи виховання.

2. Предметно-методичному - застосування педагогічної технології як окремої методики (сукупність методів і засобів реалізації певного змісту навчання і виховання в межах одного предмета).

3. Локальному (модульному) - передбачає реалізацію педагогічної технології як окремих частин навчальновиховного процесу.

В основу розвитку сучасної вищої школи повинна бути покладена концепція інформатизації освіти. Однією з ключових її позицій є базова підготовка в галузі інформатики на всіх ступенях неперервної освіти. У зв'язку з цим змінюється i роль викладачів, які повинні володіти сучасними педагогічно-інформаційними технологіями, бути готовими до роботи зі студентами в навчально-пізнавальному середовищі тощо.

3 огляду на зазначене вище, інформаційні технології характеризують: а) гнучкість - можливість викладання матеріалу 
курсу з урахуванням підготовки, здібностей студентів. Це досягається створенням альтернативного забезпечення (за рівнями) з більш детальною та додатковою інформацією, а також низки питань-підказок тощо; б) актуальність - можливість упровадження новітніх педагогічних, психологічних та методичних розробок; в) зручність - відсутність обмежень у часі для засвоєння матеріалу; г) модульність - розбиття матеріалу на окремі функціонально завершені теми (дози), які вивчаються в міру засвоєння і відповідають здібностям окремого студента чи групи загалом; д) більші можливості контролю якості навчання, які передбачають проведення самоконтролю, відсутність психологічних бар'єрів.

Все це дає підстави констатувати, що інформаційні технології навчання спрямовані на: 1) підготовку особистості інформаційного суспільства; 2) формування умінь працювати 3 інформацією; 3) розвиток комунікативних здібностей; 4) формування дослідницьких умінь та умінь вибору оптимальних рішень; 5) забезпечення великим обсягом якісної інформації.

Аналіз наукової літератури дозволив виокремити особливості інформаційних технологій навчання, а саме: 1) врахування принципу ментальності у процесі професійної підготовки; 2) використання інформаційних програмнометодичних засобів навчання 3 різних видів навчальної діяльності; 3) обгрунтування перцептивного механізму спілкування в навчальній діяльності за схемою «студент↔викладач».

Водночас слід зазначити, що інформаційні технології навчання підвищуючи активність студентів, зумовлюють перебудову навчального процесу в бік самостійного, тобто відбувається скорочення кількості аудиторних занять. Аналогічно до того, як автоматизація промислового виробництва переносить центр ваги праці фахівця на підготовку і налагодження виробничих систем, так і комп'ютеризація навчання збільшує роботу викладача 3 підготовки навчального процесу, написанню й удосконалення навчальних програм. 3 огляду на це зупинимося на поняті «навчальне середовище». Так, Я. Болюбаш, В. Грубінко, М. Степко, В. Шинкарук, зазначають, що «освітнє середовище складає сукупність зовнішніх умов, у яких відбувається повсякденна життєдіяльність індивіда, що аналізується 3 точки зору наявних у ній можливостей для формування його освіченості» [1, с. 169]. 
Реалізація інформаційних технологій в освітньому закладі включає комплекс освітніх послуг, умови становлення фахівця, структуровану систему педагогічних чинників, що впливають на підготовку тощо (див. рис. 2).

Отже, проектування освітнього простору не зводиться тільки до сукупності засобів, форм, методів, прийомів, умов тощо, а охоплюе фактично всі аспекти процесу освіти: розроблення освітніх програм і навчальних планів, засоби навчання, комп'ютерні, телекомунікаційні та ін. технічні системи, форми і методи ї використання в педагогічній практиці, рівень фахової компетентності викладачів тощо.

При цьому основними принципами запровадження інформаційних технологій у навчання виступають: 1) науковість та історизм; 2) інноваційність у поєднанні 3 традиційністю; 3) диференціація та інтеграція знань; 4) особистісно зорієнтований підхід; 5) безперервність і варіативність навчання тощо.

Розмежуємо поняття «інформаційна технологія», «інформаційний продукт». До першого відносимо сукупність методів і програмно-технічних засобів, об'єднаних у технологічний ланцюжок, що забезпечує збирання, оброблення, зберігання, поширення і відображення інформації з метою зменшення трудомісткості процесів використання інформаційних ресурсів, а також підвищення їхньої надійності та оперативності [2, с. 4]. У більш вузькому значенні термін інформаційні технології визначається як використання в навчанні різноманітних технічних засобів, зокрема й комп'ютерних.

«Інформаційний продукт» - сукупність даних, сформованих для використання в освітній діяльності.

Реалізація завдань з інформаційних технологій включає:

- інтенсифікацію навчально-виховного процесу, підвищення його ефективності та якості;

- побудову відкритої системи освіти, що забезпечить кожному студентові власну траєкторію самоосвіти;

- $\quad$ системну інтеграцію предметних знань;

- розвиток творчого потенціалу студента, його здібностей до комунікативних дій;

- $\quad$ розвиток умінь експериментально-дослідницької діяльності та культури навчальної діяльності;

- формування інформаційної культури студентів; 
- реалізацію соціального замовлення, зумовленого інформатизацією сучасного суспільства (підготовка майбутнього фахівця, спроможного використовувати в практичній діяльності інформаційні технологіі).

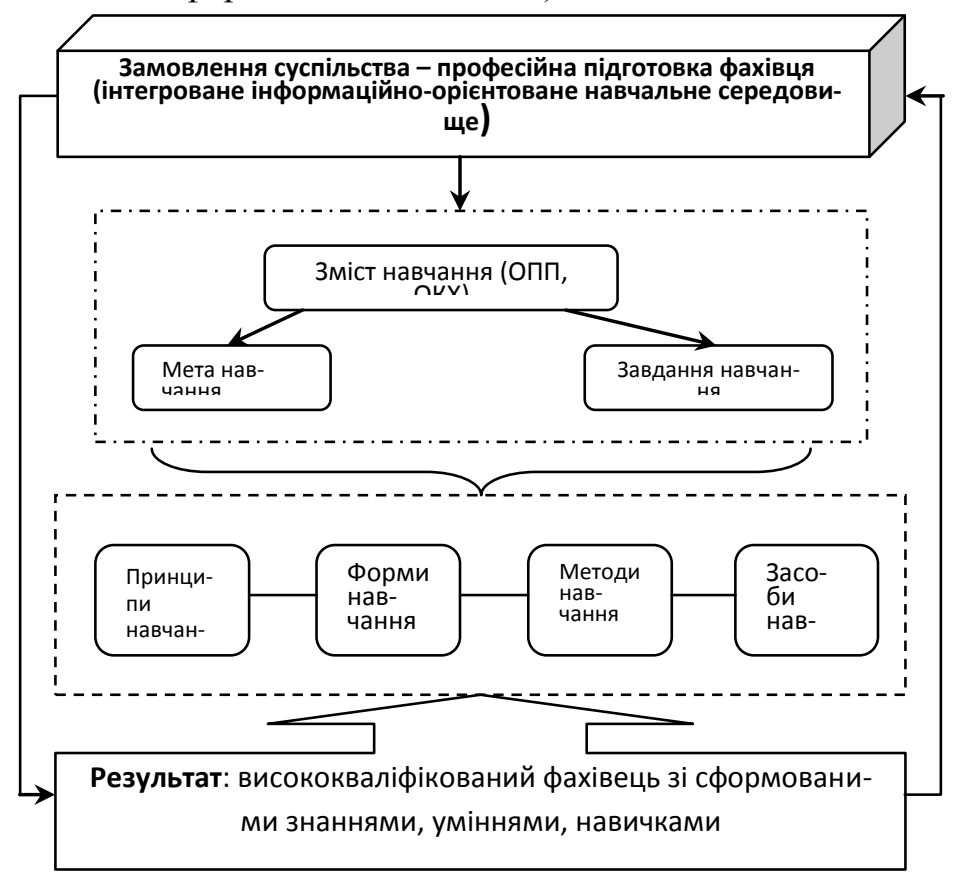

Доступність інформаційних ресурсів - один із вирішальних чинників ефективної діяльності людини. Деякі науковці ставлять його на рівні з фондом знань і умінь, якими володіє людина [3].

Отже, інформаційні ресурси - найважливіший чинник не тільки освіти, але й сучасного виробництва. Вони відкривають студентам доступ до нетрадиційних джерел інформації, підвищують ефективність самостійної роботи, дають цілком нові можливості для творчості, формування і закріплення своїх професійних навичок, дозволяють реалізувати принципово нові форми і методи навчання.

Отже, інформатизація освіти $\epsilon$ ключовою умовою успішного розвитку суспільства, яка потребує пріоритетного забезпечення відповідними ресурсами. Це процес підготовки 
людини до повноцінного життя в умовах інформаційного суспільства.

\section{Література}

1. Вища освіта України і Болонський процес : [навч. посіб.] / М. Ф. Степко, Я. Я. Болюбаш， В. Д. Шинкарук， В. В. Грубінко, I. І. Бабин ; [за ред. В. Г. Кременя]. - К. : Освіта, 2004. - 384 с. 2. Дибкова Л. М. Інформатика і комп'ютерна техніка : [навч. посіб.] / Л. М. Дибкова. - К. : Академвидав, 2005. - 416 с. 3. Дичківська І. М. Інноваційні педагогічні технології : [навч. посіб.] / I. М. Дичківська. - К. : Академвидав, 2004. - 352 с. 4. Зязюн І. А. Освітні технології у вимірах педагогічної рефлексії / І. А. Зязюн // Світло. - 1996. - № 1. - С. 4. 5. Фіцула М. М. Педагогіка вищої школи : [навч. посіб.] / М. М. Фіцула. - К. : Академвидав, 2006. -352 с.

УДК 378:004

\author{
Н. Т. Тверезовська, \\ доктор пед. наук, професор, \\ Д. Ю. Касаткін, \\ ст. викладач, \\ Національний університет біоресурсів $i$ \\ природокористування України
}

У статті розглянуто особливості навчання студентів у комп 'ютерноорієнтованих навчальних середовищах; визначено загальнодидактичні й специфічні принципи роботи; надано характеристики, властиві комп'ютерно-оріснтованим навчальним середовищам.

Ключові слова: навчальне середовище, принципи, дистанційна освіта, інформаційно-комунікаційні технологї.

В статье рассмотрень особенности обучения студентов в компьютерно-ориентированных учебных средах, определены общедидактические и специфические принципы работы; представлены характеристики, свойственные компьютерно-ориентированным учебным средам.

Ключевые слова: учебная среда, принциипь, дистанционное образование, информационно-коммуникационнье технологии.

The features of student learning in computer-oriented learning environments are defined; general didaktic and specific principles of operation, the characteristics inherent in computer-oriented learning environments are given.

Key words: learning environment, principles, distance education, information and communication technology. 